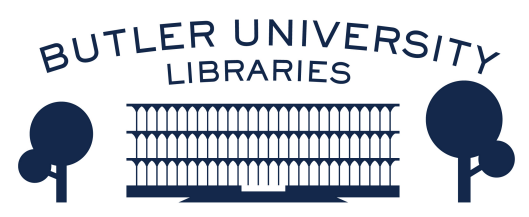

Journal of Hindu-Christian Studies

Volume 15

Article 6

January 2002

\title{
The Politics and the Dharma of Conversion: Reflections from the Mahabharata
}

Arti Dhand

Follow this and additional works at: https://digitalcommons.butler.edu/jhcs

Part of the Religion Commons

\section{Recommended Citation}

Dhand, Arti (2002) "The Politics and the Dharma of Conversion: Reflections from the Mahabharata," Journal of Hindu-Christian Studies: Vol. 15, Article 6.

Available at: https://doi.org/10.7825/2164-6279.1273

The Journal of Hindu-Christian Studies is a publication of the Society for Hindu-Christian Studies. The digital version is made available by Digital Commons @ Butler University. For questions about the Journal or the Society, please contact cbauman@butler.edu. For more information about Digital Commons @ Butler University, please contact digitalscholarship@butler.edu. 


\title{
The Politics and the Dharma of Conversion: Reflections from the Mahabharata
}

\author{
Arti Dhand \\ University of Toronto
}

THIS reflection is in the context of trends of the last decade in India, in which some Hindu nationalists have resisted the proselytizing activities of Christian missionaries with tactics of intimidation and terror.

The question of conversion has been a vexed one for Hinduism since its earliest encounters with other faiths, as perhaps it must be for every tradition. Anxiety over the conversion of Hindus to Islam was a serious concern in mediaeval India, and fear of Hindus converting to Christianity formed part of the backdrop against which the renascent Hindu movements of the 19th and 20th centuries articulated and defined themselves. But the issue of conversion goes much further back, to the pre-Common Era debates among the orthodox and the heterodox traditions. Asoka's generous patronage of Buddhism was a source of anxiety to the orthodox in the 3rd century $\mathrm{BCE}$, and Pusyamitra Sunga's reestablishment of Brahmanical orthodoxy in the 2nd century BCE was in some sense an act of Hindu imperial self-assertion. The question of how to deal with alien belief systems, then, has always been pertinent for Hinduism. In the following short essay, I will consider the topic of conversion from the perspective of my specialization in the Hindu epics, and from my work on Hindu ethics. I will examine first the Mahabharata's attitude to rival faiths, and see if it has any insights to offer on the contemporary situation. Following that, I will attempt a response to the issues raised by this thorny topic from the perspective of Hindu ethics.

\section{The Mahabharata and Conversion}

The issue of conversion is not, to my knowledge, specifically debated in the Mahabharata. What we might hope to learn from looking at the Great Epic, therefore, is what attitudes the epic might have had to foreign ideas, how these were accommodated or rejected, and the extent to which the rejection condoned the use of violence.

Scholarly conjecture places the composition of the Mahabharata in the four hundred years surrounding the turn of the millennium for BCE to CE, circa $200 \mathrm{BCE}$ to $200 \mathrm{CE}$. This was a critical period in the formation of Hindu orthodoxy, as it morphed from its ritualistic Vedic phase to its classical phase, in which most of the elements of later Hinduism were developed and articulated. Hindu beliefs were formulated, refined, and rehearsed in active dialogue with several rival groups, the most significant among whom were the Ajivakas, the Buddhists, and the Jains. These groups serve as the unacknowledged opponents, the purvapaksins, against whom the Mahabharata refined its theological

Arti Dhand is Assistant Professor at the Department and Centre for the Study of Religion at the University of Toronto, Canada. Her primary research interests are the Hindu epics, Hindu ethics, History, and Gender Issues. Her most recent work has focused on ethical issues in Hinduism. She is presently working on a book on Women and Sexuality in the Mahabharata. 
positions. How is the Mahabharata disposed to these groups?

The Mahabharata does not have one attitude to foreign ideas. Overall, we find that while it condemns the radical repudiation of the Vedas, it does take cognizance of the arguments of its detractors, and responds to them after weighing the factors carefully. In some cases, it is informed by the insights of other groups and absorbs them, theorizing them, however, in a specifically Hindu idiom. This is the case for the Jain teaching of ahimsa Hinduism, through its epics, early affirmed the primacy of ahimsa as a cardinal ethic, and includes it in numerous lists detailing high ethics. Unlike Jainism, however, it never abjured violence altogether. While it maintained a high esteem for ahimsa, Hinduism retained a pragmatic acknowledgement of the fact that one can't get along in the world without causing some degree of harm to other beings. Many passages in the Mahabharata struggle with this question: while ahimsa is an excellent ideal, how does one live in the world without somehow imposing upon, exploiting, or harming other beings. As one passage recognizes, "there are many creatures in water, in soil, and in fruit"; indeed, "there are many creatures that are so minute that their existence can only be inferred. With the falling of the eyelids alone, they are destroyed" (XII.15.25-26). How, then, is it possible to get away from violence?

The tradition responded to this question in several ways. One way was to uphold the stern application of ahimsa for those ambitious few who are on the final quest, the search for moksa, and to propose a more modest goal for the majority, that of anrsamsya, "non-cruelty". This would have the effect of displacing the emphasis from one's actions to one's intentions. The other, more common, response of the tradition in the classical period was to reluctantly admit the necessity of violence, but to control it rigorously, to scrutinize its purposes, and to oversee its functioning. Violence was admitted, but limited to certain classes of people, certain times, certain places, for certain durations of time, and only for certain purposes. Thus, the violence associated with war was accepted as a necessity for the orderly functioning of dharma, but it was to be limited to the ksatriya class, to the battlefield, for the duration of the battle, and for the defense of dharma; moreover, one must have exhausted all alternatives first, before resorting to violence. The violence associated with agriculture was appropriate for vaisyas, but only in the context of their productive work, and for the duration of the work. The violence associated with government was accepted as a necessity for maintaining order in society, but was again circumscribed and contained within specified boundaries. Wanton displays of violence were strongly condemned. Thus, while a ksatriya was expected to be aggressive and forceful in the fury of battle, he was not permitted to go home and beat his wife (XIII.App.I.14.879). While a vaisya may of necessity injure creatures in the course of farming, he was not justified in neglecting his arimals or in torturing little insects. Violence had closely circumscribed limits, and these were to be scrupulously observed. Finally, the most important consideration in the use of violence may be taken from the Gita: violence is not to be undertaken for the sake of any self-serving ends. Rather, it is to be performed in a spirit of passionlessness, with equanimity, only where it is an absolute duty, and without seeking any personal goal.

These are some of the ways in which the Mahabharata accommodates the insights of the rival tradition of Jainism, embracing ahimsa, but theorizing it anew. How does the Mahabharata deal with Buddhist ideas?

The Mahabharata assumes many elements of the larger Indic worldview that is affirmed by Buddhism. As a result, the attitudes of the Mahabharata and Buddhism (and Jainism, for that matter) tend to be similar on many points. So, for example, in its 
ascetic strains, the Mahabharata expresses as profound a disdain for the body as to be found in any early Buddhist tract. Similarly, in the ascetic strains, the understanding of human experience is indeed that the world is a painful and disappointing place to be, and that the solution to the misery of the world is to gear oneself for a higher enlightenment that will bring one freedom from the bondage of samsara. These ideas are as common to the Samkhya platform of the Mahabharata as they are to Buddhism. More specifically Buddhist ideas are debated in Chapter 211 of the Santiparva of the Mahabharata. In these passages, two points are specifically rejected: one is the Buddhist repudiation of the Veda. The other point is the doctrine of anatman. The Mahabharata rejects this as an erroneous view.

Does the Mahabharata anywhere advocate violence to resist conversion, or to combat different ideological points of view? It seems safe to say that the Mahabharata does not welcome the conversion of those who believe in the Vedas and does not hold those adopting heterodox views in high regard. But while inimical views are occasionally reviled, it is clear that these polemics are part of an ongoing dialogue, and there is a recognition, however tacit, that there is merit to the critiques of the heterodox schools. As noted above, their criticisms are seriously pondered and engaged. Beyond that, there is a fair acceptance of different forms of belief. One passage from the Santiparva is particularly enlightening on this point. In this, Yudhisthira asks the grandsire Bhisma to evaluate the merits of Samkhya and Yoga, given their differing theological outlooks: the non-theistic framework of Samkhya and the theistic framework of Yoga. Which one is better? The wise Bhisma responds with the judgment that while each has its biases, both are worthy. Both impart learning, and both lead to the truth if followed faithfully (XII.289.2-9). This statement is a remarkable and clear-headed acknowledgement that both theistic and non- theistic worldviews lead to salvation; the important consideration is the sincerity with which they are practised. The question of identity is still an issue: the text assumes an identity framed and sustained by a belief in the authority of the Vedas. There are other passages, however, that relativize all social boundaries demarcating Self and Other. In the spectacular Sulabha-Janaka-samvada of the Santiparva, for example, the sage Sulabha argues tenaciously for the high ideals of Hinduism: if, she says, one is truly enlightened, what is the Self, and what is the Other? How is it possible to differentiate one from another? Only a naïve and unenlightened individual can distinguish between them; the enlightened one knows that these are but modifications of prakrti. There is no fundamental difference. (XII.308)

Given the highest ideals of the Hindu tradition, then, there is no basis for making such distinctions between individuals as would make some groups the targets of persecution. At a lower level of knowledge (and the Mahabharata is famously polyvocal, addressing different levels of insight simultaneously), the Mahabharata affirms an orthodox identity, and in defence of this identity, engages in polemical debate. We do not, however, hear anything suggesting gross intimidation of, or violence against a rival group. Violence is supported in many contexts in the Mahabharata-in a just war, in disciplining criminals, sometimes in sacrifice-but nowhere is it advocated for resistance to proselytization, or for the propagation of 'one's own belief system.

Dissenters might protest that the Mahabharata's discourse with Buddhism and Jainism is no analogue to the current situation between Hinduism and Islam and Christianity. The argument might go that Buddhism and Jainism are traditions of the same soil as Hinduism, have the same roots and therefore belong as much to Bharat mata as does Hinduism. This Savarkarian argument, however, is untenable, being 
decidedly anachronistic. While it is true that Hinduism did eventually reconcile with the heterodox faiths by absorbing many of their elements and appropriating some of their key figures, in its early phases, the relationship between the heterodox communities and the orthodox Brahminical community was very much antagonistic. The heterodox viewpoints were viewed as being in every way as alien and downright heretical as Christianity or Islam might seem to some right-wing Hindus today. Indeed, their presence and increasing popularity represented nothing short of intimations of the end of the world. Heterodox philosophies and lifestyles were interpreted as signs of the arrival of the kaliyuga, and in the epics and the Puranas, we read the real despair that the orthodox community experienced at what it interpreted as an erosion of its most cherished beliefs. The above might be termed the Mahabharata's political interaction with other faiths. What lessons might one learn from the Mahabharata's ethics for the current situation with Christian missionaries?

\section{Hindu Ethics: Ksatriya Dharma}

Hindu revivalists menacing missionaries and converts with their weapons and their show of manly force project themselves in the image of the ksatriya hero, the warrior who acts in the defence of his Hindu dharma. This is, however, an egregiously narrow interpretation of ksatriya dharma. Both the Hindu epics make explicit that ksatriya dharma, first and foremost, dictates the protection of the weak by the strong, the defence of those who have no recourse to defend themselves, the support of the powerless against tyranny. This is very clear in the Mahabharata: the ksatriya class is said to be destroyed in the great Bharata war specifically because, instead of protecting and defending the peace-speaking Brahmin community, it savagely attacked them. In both epics, ksatriyas approached by the other classes are honour-bound to protect them. So Yudhisthira cannot be persuaded by any inducement to abandon even a humble mongrel in the Mahaprasthanikaparva. The legendary King Sibi Usinara offers his own flesh to a predatory hawk to save the life of a bird in the Aranyakaparva. The Pandava Arjuna voluntarily takes exile rather than shirk his duty to assist a Brahmin who has sought his help in the Adiparva. This is the moral essence of ksatriya dharma: the protection, the defence, the support of the weak by the strong-if necessary, even with the price of one's own life. Numerous passages in the Mahabharata are emphatic in their statement that the ideal man is one who assures all beings of his compassion (XII.237.8-26).

It is plain enough to see, then, that Hindus persecuting impoverished Dalits and hapless Christian missionaries represent in every way the antithesis of the ideal of the ksatriya. They take advantage of their own position of strength to prey upon the vulnerabilities of the weak. Far from inspiring the confidence of people by their protectiveness, they terrorize those who are helpless. Finally, although they claim to be the defenders of Hinduism, they violate the tradition's most precious ideal: that of acting without motive, without the desire to gain any personal ends. Characters of this ilk are clearly motivated by a frenzied xenophobic zeal, an impassioned desirousness that represents the precisely opposite disposition to that taught by the vast resources of the Hindu tradition. They are poor representatives of Hinduism, and Hindus need to resist their efforts to usurp the tradition for their own narrow and nefarious causes.

\section{Hindus and Christian Missionaries}

Hindu nationalists engaged in these exercises identify two issues that they see as being problematic about conversion: 1) proselytization, and 2) allurement.

On the position that Christian missionaries "lure" the adivasis away from 
"Hinduism" with promises of a better material life, it's difficult to assume too stern a stance on this point. Granted that material inducements should never enter the equation in a question of faith, but as Hindus, we need to face the fact that the reason such crude allurements work is because of Hinduism's own long history of abuse of its underclasses. If we as Hindus are seriously concerned that other religious groups are going to lure our disenfranchised classes away because of Hinduism's past track record, then the onus is on us to make amends - not through the ostentation of ritual, but by working to create a Hinduism that is responsible and responsive to all classes of its adherents, of every hue and colour. And the sooner, the better.

Proselytization continues to be a provocative issue because since the colonial period, (and notwithstanding the Indian Christian communities of hoary antiquity), Christianity has been equated with the colonial power structure. In colonial times, Christianity's claims to religious superiority directly paralleled the colonial government's rhetoric of racial superiority, both with their often blistering condemnation of India and its religions. This had the effect of forging in the minds of nationalists a link between Christianity and dominance. It would be naïve to suggest that in post-colonial times, this power imbalance has vanished, and that Christianity no longer represents the coercive power, wealth, and political might of the Western world. The question, however, is whether individuals of the different faith, even the dominant faith, should be barred from proselytizing. There is nothing in Hindu ethics to support this. If we return to the Mahabharata, we see that the tradition debated many perspectives on religion, and although it engaged in many heated polemical debates with people of other viewpoints, it accepted their existence. Indeed, the Buddhist and Jain traditions were a crucial reference point in the definition of Hinduism.
Hinduism has also had the wisdom to recognize that people have natural religious predilections, religious gifts, talents, insights, vocations. So it has generally accommodated different means of practice, different ways of being religious, even entirely different ways of perceiving the world. It may be the only tradition in the world today where it's possible to be a committed. monotheist, an eclectic polytheist, an insightful pantheist, a rational atheist, or one who maintains that the question of God is entirely irrelevant to the religious pursuit - and still be authentically Hindu! Even in periods where esteem for the religious acumen of women was deplorably low, it recognized the religious talents of women; even in periods where its social cloak was stiff and unbending with orthodoxy, it acknowledged the religious insights of its lowest classes. There can be no compulsion in religious matters. One must be cautious about dismissing the religious experiences of others.

\section{Conversion as a Personal Issue}

Ultimately, the question of how to deal with conversion and proselytization is not a philosophical conundrum; it is most immediately a personal one. All individuals living in proximity to missionary faiths must deal with it, and must determine for themselves how they will resolve it. If I may be permitted a personal departure here, the questions of proselytization and conversion are ones I've encountered repeatedly in my life, both as an academic and as an individual. I grew up in a Catholic boarding school in India, and from adolescence, have lived in the predominantly Christian environment of Canada. I can't count the number of times people have tried to convert me to different brands of Christianity. I had always considered myself to be a liberal individual, but in principle I resisted proselytization. I don't foist my beliefs on you, I always thought, don't foist yours on me. But my pluralist credentials were 
challenged one day by a Hindu friend who scandalized family and community by suddenly and publicly converting to Christianity. He then embarked upon a peculiar and, for his friends, embarrassing course of action: standing at street corners handing out pamphlets to people, approaching complete strangers and talking to them about Christ, exposing himself sometimes to ridicule and rebuff. One might have dismissed him as another confused diasporic Hindu, or one who had in despair succumbed to the pressures of the mainstream, but this was not so easy, for he was no ordinary fellow - intellectually gifted, morally scrupulous, of a highly rational and contemplative bent of mind; in short, not to be dismissed. He had his friends perplexed. Then one day he described his experiences to me. What if, he said, you experience something so powerfully that if you don't share it with other people, you believe you are committing a real evil? What if your faith actively calls you to tell everybody you know, and to try to make them believe the same thing, because if you don't, you're sure you're participating in wrongdoing? He asked me: Can you accept that? And if you can't accept that, then can you still call yourself a pluralist? I was silenced.

Of course, in a democratic and pluralist country, people have the right to right to share their views, just as others have every right to refuse the message. No religious arguments should eclipse the fact that in modern times, India bills itself as a secular and pluralist nation that enshrines the right of all people to practice their faiths. But the issue here is a moral one, for Hinduism. In my view, Hinduism has generally been alert to the fact that people are called to religious vocations by different routes. Our world is small. Daily we bump elbows with people of different religions and belief systems. Even if we want to embrace our tribal identities, we cannot ignore the very real presence of other people. The only humane recourse is to learn again from each other: to take seriously again, for example, the pluralist Jain ideal of anekantavada, to practice our own faiths, and to allow the others the same liberty, even if that means we have to put up. with the inconvenience every so often of having them try to persuade us of their point of view. Perhaps what we need most is a sense of humour. I myself have come to the point where I enjoy sparring with Christian missionaries who come to my door, and occasionally even coach the novices on their debating skills. I don't feel my Hindu identity threatened by this. Indeed, I feel my actions and my ethics to be informed by the ideals of Hinduism.

To conclude this reflection on a personal note, nowhere in my study of Hindu ethics have I found it said that if people think differently from you, you should kill them. Nor have I found it stated that if they try to convince you of their views, you should kill them, or if people convert to alien views, you should kill them. If anything, Hindu history is a study in learning from other traditions, absorbing what is lofty and sober, and discarding the excess. The Mahabharata says, ignorance is the only obstacle to liberátion. To obliterate ignorance, one should with reverence accept instruction from whomsoever has the wisdom: "Acquiring knowledge from a brahmin or kshatriya or vaishya or even a shudra of low birth imparted graciously, one should accept it with confidence...All varnas are brahmins. All are born of Brahman, and all constantly utter Brahman. With the knowledge of Brahman, of truth and of the shastras, I say this whole universe is pervaded by Brahman" (XII.306.85-6).

If we are to take our cue about Hindu identity from anywhere, it seems to me that the firmest ground in which to root ourselves is the alluvial richness of Hindu ideals. 
12 Arti Dhand

\section{Works Cited}

Mahabharata (Crit. Ed.). 19 vols. V.S. Sukthankar et al., eds. (Poona: Bhandarkar Oriental Research Institute, 1927-59).

Chapple, Christopher Key. Non-violence to Animal, Earth, and Self in the Asian Traditions (Albany: SUNY Press, 1993).
Hiltebeitel, Alf. Rethinking the Mahabharata: A Guide to the Education of the Dharma King (Chicago: University of Chicago Press, 2001).

Lath, Mukund. "The Concept of Anrsamsya in the Mahabharata," The Mahabharata Revisited. Ed. R.N. Dandekar. (New Delhi: Sahitya Akademi, 1990), 113-119. 